Nanik Setyawati, Riyadi Santosa, Sumarlam, Dwi Purnanto - Modalitas sebagai Peranti Sistem Appraisal dalam Teks Iklan Kuliner Khas Semarang di Media Internet

\title{
MODALITAS SEBAGAI PERANTI SISTEM APPRAISAL DALAM TEKS IKLAN KULINER KHAS SEMARANG DI MEDIA INTERNET
}

\author{
Nanik Setyawati \\ Universitas PGRI Semarang, Semarang, Indonesia \\ Email: n.setyawati.71@gmail.com \\ Riyadi Santosa \\ Universitas Sebelas Maret, Surakarta, Indonesia \\ Email: riyadisantosa@staff.uns.ac.id \\ Sumarlam \\ Universitas Sebelas Maret, Surakarta, Indonesia \\ Email: sumarlam@staff.uns.ac.id \\ Dwi Purnanto \\ Universitas Sebelas Maret, Surakarta, Indonesia \\ Email: dwipurnanto@staff.uns.ac.id
}

\section{Article history:}

Submitted Oct 14, 2020

Revised Dec 07, 2020

Accepted Feb 02, 2021

Published June 12, 2021

\begin{abstract}
Persuasive power in the language of advertising can be reflected in the structure of words, phrases, or clauses in the contents of written or spoken advertisements. Most ad text uses verbal and nonverbal symbols to convey the intent and purpose. The use of language in advertising is adjusted to the needs and to achieve the purpose of the ad. Linguistic research specifically looking at appraisal devices in culinary text advertisements on the internet has an important role in uncovering the ideology of their makers. Through appraisal device studies, especially modalities in ad text on the internet media will be able to know and understand the attitude of advertisers towards the reality that surrounds them, namely their assessment of the advertised goods and the assessment of their environment. This qualitative research refers to Sudaryanto's opinion in providing data and data analysis. Provision of data using the method of referencing and note taking. Data analysis methods and techniques use the method of sharing with basic techniques, namely techniques for direct elements; while the advanced technique uses the technique of fade and dressing techniques. Through a series of analyzes, it was found that there was a use of modality: intentional, epistemic, deontic, and dynamic in the culinary ad text typical of Semarang.
\end{abstract}

Keywords: appraisal; culinary ad text; modality; internet 


\begin{abstract}
ABSTRAK
Daya persuasif pada bahasa iklan dapat direfleksikan dalam struktur kata, frasa, maupun klausa pada isi iklan yang tertulis atau terlisankan. Sebagian besar teks iklan menggunakan lambang verbal dan nonverbal untuk menyampaikan maksud dan tujuannya. Pemanfaatan bahasa dalam iklan disesuaikan dengan kebutuhan dan untuk tercapainya maksud iklan tersebut. Penelitian kebahasaan yang secara khusus menyelisik peranti appraisal dalam teks iklan kuliner di media internet memiliki peranan penting untuk mengungkap ideologi pembuatnya. Melalui kajian peranti appraisal, khususnya modalitas dalam teks iklan di media internet akan dapat diketahui dan dipahami sikap pengiklan terhadap realitas yang mengelilinginya, yaitu penilaiannya terhadap barang yang diiklankan dan penilaian terhadap lingkungannya. Penelitian kualitatif ini mengacu pendapat Sudaryanto dalam penyediaan data dan analisis data. Penyediaan data menggunakan metode simak dan teknik catat. Metode dan teknik analisis data menggunakan metode agih dengan teknik dasar, yaitu teknik bagi unsur langsung; sedangkan teknik lanjutan menggunakan teknik lesap dan teknik ganti. Melalui serangkaian analisis, ditemukan hasil bahwa terdapat adanya penggunaan modalitas: intensional, epistemik, deontik, dan dinamik dalam teks iklan kuliner khas Semarang.
\end{abstract}

Kata kunci: appraisal; modalitas; teks iklan kuliner; internet

\title{
PENDAHULUAN
}

Hampir setiap hari manusia dihadapkan dengan berbagai iklan, baik di majalah, surat kabar, televisi, radio, internet, maupun di berbagai tempat yang memungkinkan. Komunikasi yang persuasif dapat dijumpai dalam bahasa iklan. Bahasa dalam periklananan digunakan untuk mempengaruhi orang lain atau konsumen. Daya persuasif pada bahasa iklan dapat direfleksikan dalam struktur kata, frasa, maupun klausa pada isi iklan yang tertulis atau terlisankan.

Sebagian besar teks iklan menggunakan lambang verbal dan nonverbal untuk menyampaikan maksud dan tujuannya, namun terdapat sebagian menggunakan simbol-simbol tertentu yang melambangkan produk-produk yang akan dipasarkan dan diperkenalkan kepada masyarakat luas. Pemanfaatan bahasa dalam iklan tentu saja disesuaikan dengan kebutuhan dan demi tercapainya maksud iklan tersebut.

Penelitian kebahasaan yang secara khusus menyelisik peranti appraisal dalam teks memiliki peranan penting untuk mengungkap ideologi 
Nanik Setyawati, Riyadi Santosa, Sumarlam, Dwi Purnanto - Modalitas sebagai Peranti Sistem Appraisal dalam Teks Iklan Kuliner Khas Semarang di Media Internet

pembuatnya. Salah satu aspek yang menjadi bagian dalam pembahasan appraisal, yaitu modalitas. Berdasarkan pengamatan penulis, terdapat beberapa kajian yang telah membahas seputar modalitas, di antaranya adalah: Prihantoro \& Fitriana (2015); Karsana (2015); Musdolifah (2018); Khaofia (2018); dan Aisyah (2019).

Dalam pembahasan tentang "Modalitas dalam Teks Berita Media Online" Prihantoro \& Fitriana (2015) ditemukan adanya penggunaan kalimat positif dan kalimat negatif yang di dalamnya terdapat jenis modalitas intensional, epistemik, deontik, dinamik, dan aletis (dengan unsur kata yang ditemukan adalah ingin, mau, mungkin, pasti, izin, boleh, bisa, dapat, mampu, dan harus).

Karsana (2015) dalam “Mengurai Dilema Modalitas dalam bahasa Kaili (Parse Dilemma Modality in Kaili Language)" menemukan adanya lima jenis modalitas dalam bahasa Kaili, yaitu modalitas intensional, epistemik, deontik, dinamik, dan aletis. Penanda leksikal yang terlihat adalah mbeki 'ingin', madota 'mau', patuju 'maksud', sarumaka 'harap, nerapi 'mohon', soba 'coba', tulungi 'tolong', kai 'mari', kamai 'ayo', anumo 'silakan', palamba 'biar', mo- 'akan', bara 'mungkin', tantu 'pasti', dopa tantu 'belum pasti', kana 'harus', nombadekei 'izin', nevali 'bisa', namala 'dapat', nompakule 'mampu', dan paralu 'perlu'.

Dalam kajian “Keterangan Modalitas dalam Berita Alexis yang Terus Axis pada Majalah Tempo Edisi 29 Januari - 4 Februari 2018" yang dibahas oleh Musdolifah (2018) adanya empat wujud keterangan modalitas intensional, epistemik, dinamik, dan deontik. Unsur kata yang ditemukan adalah ingin, antusias, berjanji, seharusnya, meyakini, membenarkan, menurut, sepertinya, kemungkinan, bisa, dan izin. Selain itu, terlihat adanya perspektif positif dan negatif dari penulis berita Majalah Tempo dalam menanggapi wujud keterangan modalitas tersebut.

Khaofia (2018) dalam penelitian “Modalitas sebagai Realisasi Makna Interpersonal dalam Mata Najwa on Stage Semua Karena Ahok" mengurai status yang dikaji yaitu posisi interpersonal antara Najwa Shihab dengan nara sumber 
pada talk show. Hasilnya menunjukkan bahwa posisi Najwa tidak sejajar dengan partisipan lain dalam talk show. Penggunaan modalitas tingkat tinggi dan obligasi menyatakan keinginan yang kuat Najwa untuk menguasai percakapan dalam talk show. Najwa sebagai pihak yang mendominasi, pengatur jalannya talk show, memiliki keluasan dalam merancang isi talk show, dan melakukan kebebasan untuk memilih informasi yang ingin didengar atau yang ingin dilakukan oleh partisipan.

Aisyah (2019) dalam “Modalitas Bahasa Indonesia dalam Talk Show Mata Najwa" ditemukan adanya modalitas yang berjenis intensional, epistemik, deontik, dan dinamik. Satuan lingual modalitas yang ditemukan adalah mari, harus, empati, bisa, jangan sampai, harus, silakan, dan sanggup.

Berdasarkan review pada lima jurnal di atas, peneliti masih mempunyai kesempatan untuk mengadakan penelitian yang bersumber dari teks iklan dengan memfokuskan pada kajian sistem appraisal. Pada kesempatan ini peneliti akan berfokus pada kajian modalitas yang terdapat pada teks iklan kuliner khas Semarang di media internet. Fokus kajian tersebut secara khusus belum dikaji oleh peneliti-peneliti sebelumnya. Melalui kajian peranti appraisal, khususnya modalitas dalam teks iklan di media internet akan dapat diketahui dan dipahami sikap pengiklan terhadap realitas yang mengelilinginya, yaitu penilaiannya terhadap barang yang diiklankan dan penilaian terhadap lingkungannya. Penelitian ini bertujuan untuk mendeskripsikan jenis modalitas yang terdapat pada teks iklan kuliner khas Semarang di media internet.

\section{TEORI DAN METODE PENELITIAN}

Penelitian ini merupakan penelitian bahasa yang mendasarkan pada analisis teks. Analisis teks merupakan analisis atas teks yang terdapat dalam wacana (Fairclough dalam Prihantoro, 2015:17). Teks merupakan bahasa yang diberdayakan dalam proses komunikasi (Faradi, 2015:235). Di dalam sebuah teks kalimat, terdapat suatu keterangan yang disebut modalitas. Modalitas menerangkan cara pembicara menyatakan sikap terhadap suatu situasi dalam 
Nanik Setyawati, Riyadi Santosa, Sumarlam, Dwi Purnanto - Modalitas sebagai Peranti Sistem Appraisal dalam Teks Iklan Kuliner Khas Semarang di Media Internet

suatu komunikasi antarpribadi (Kridalaksana, 1993:138). Hal ini ditandaskan oleh Charmilasari (2018:138) yang menyatakan bahwa modalitas merupakan pertimbangan atau pendapat pribadi penutur atas pesan yang dituturkan saat berinteraksi. Hal ini ditandaskan Amrullah (2020:38) bahwa modalitas diklasifikasikan atas modalisasi yang merupakan pendapat atau pertimbangan pribadi pemakai bahasa.

Modalitas sangat terkait dengan modus. Modus dan modalitas digunakan sebagai paradigma verba atau sistem verbal dalam mendeskripsikan karakteristik bahasa (Oktavianti, 2018:181). Suatu kalimat dikatakan bermodus jika di dalamnya terkandung konsep modalitas. Dalam hal ini, kalimat yang tidak mengandung konsep modalitas disebut sebagai kalimat yang modusnya tidak tertanda. Modalitas dapat berbentuk kata, frasa, maupun klausa. Alwi (1992:259-261), Chaer (1994:262-263), dan Cahyadi (2015:1), membagi modalitas menjadi empat macam, yaitu modalitas intensional, epistemik, deontik, dan dinamik.

Modalitas intensional merupakan modalitas yang menyatakan 'keinginan', 'harapan', 'ajakan', 'pembiaran', dan 'permintaan' (Alwi, 1992:36). Makna 'keinginan' dinyatakan dengan unsur leksikal, seperti: ingin, menginginkan, mengingini, berkeinginan, menghendaki, berhasrat, mendambakan, mau, hendak, akan, bertekad, berketetapan, bermaksud, berniat, berhajat, bernadar, dan berkaul. Makna 'harapan' dinyatakan dengan pengungkap, seperti: harap, harapkan, mengharapkan, mengharap, berharap, hendaknya, berdoa, doakan, mendoakan, mudah-mudahan, moga-moga, dan semoga. Makna 'ajakan' dan 'pembiaran' dinyatakan dengan unsur leksikal, seperti: ajak, mengajak, imbau, mari (lah), ayo (lah), mengimbau, biar (lah), dan biarkan (lah). Kata sudilah, sukalah, saya minta, saya mohon, silakan, coba, tolong, dan mohon sebagai penanda makna 'permintaan' (Alwi, 1992:259 - 260).

Modalitas epistemik adalah modalitas yang menyatakan 'kemungkinan', keteramalan, 'keharusan', atau 'kepastian' (Alwi, 1992:91). Pengungkap makna 'kemungkinan' dapat dipaparkan melalui kata dan frasa tertentu. Yang berupa 
kata ialah dapat, bisa, boleh, mungkin dan barangkali; sedangkan yang berupa frasa ialah dapat saja, bisa saja, boleh saja, bisa bisa bisa jadi, dan boleh jadi. Pengungkap makna 'keteramalan' yang berbentuk kata ialah akan, dikira, diduga, konon, sepertinya, agaknya, tampaknya, nampaknya, rasanya, kelihatannya, diperkirakan, kabarnya, rasa-rasanya, dan kayaknya; sedangkan yang bentuk klausa ialah saya pikir, saya rasa, saya kira, saya duga, dan \{menurut pada\} saya, dan \{pendapat hemat\} saya. Penanda makna 'keharusan' berupa kata harus, mesti, wajib, perlu, patut, seharusnya, semestinya, sebaiknya, sepantasnya, seyogianya, selayaknya, sepatutnya, patut-patutnya, dan pantas-pantasnya. Kata pasti, tentu, tentunya, niscaya, dan dipastikan; frasa tentu saja dan sudah barang tentu; dan klausa saya yakin, saya percaya, saya merasa pasti, dan saya memastikan sebagai pengungkap modalitas 'kepastian' (Alwi, 1992: 260 - 261).

Modalitas deontik mencakup makna 'izin' dan 'perintah'. Modalitas deontik bersifat subjektif yang menggambarkan bahwa pembicaralah yang memberikan perintah, izin, atau bahkan larangan kepada seseorang untuk melakukan sesuatu. Dengan kata lain, kesubjektifan pada modalitas deontik berkaitan dengan pandangan pembicara terhadap peristiwa (Alwi, 1992:23). Makna 'izin' dapat diungkapkan melalui kata boleh, dapat, bisa, perkenankan, memperkenankan, diperkenankan, izinkan, mengizinkan, diizinkan, perbolehkan, memperbolehkan, dan diperbolehkan. Sementara itu, untuk pengungkapan makna 'perintah' dapat dipaparkan melalui kata wajib, mesti, harus, haruskan, mengharuskan, diharuskan, perintahkan, memerintahkan, diperintahkan, larang, melarang, dilarang, tidak boleh, dan jangan (Alwi, 1992:261).

Modalitas dinamik sama dengan modalitas deontik yang mempersoalkan sikap pembicara terhadap aktualisasi peristiwa (Alwi, 1992:233). Modalitas dinamik ini mencakup modalitas kemampuan yang diungkapkan melalui dapat, sanggup, bisa, dan mampu (Alwi, 1992:261).

Jenis penelitian yang digunakan dalam kajian ini adalah penelitian kualitatif. Bogdan dan Taylor (1975:5, dalam Moeleong, 2010:4) mendefinisikan penelitian kualitatif sebagai prosedur penelitian yang menghasilkan data 
Nanik Setyawati, Riyadi Santosa, Sumarlam, Dwi Purnanto - Modalitas sebagai Peranti Sistem Appraisal dalam Teks Iklan Kuliner Khas Semarang di Media Internet

deskriptif berupa kata-kata tertulis atau lisan dari orang-orang dan perilaku yang dapat diamati. Penelitian ini menggunakan fenomena linguistik sebagai data, khususnya modalitas dalam iklan kuliner khas Semarang di media internet. Penelitian ini tidak menggunakan prosedur statistik atau bentuk penghitungan lain karena penelitian ini akan melihat sifat alamiah data yang menggelar modalitas dalam iklan kuliner.

Sumber data merupakan sumber dari mana data itu diperoleh (Santosa, 2017:52). Di dalam penelitian sumber data dapat berupa tempat, informan, kejadian, dokumen, situs, dan lain sebagainya. Sumber data dalam penelitian ini diambil dari media internet jenis layanan website. Website menjadi pilihan yang diambil dengan pertimbangan bahwa iklan di website mudah dikenal oleh masyarakat luas. Promosi produk dengan layanan website juga dapat dilakukan selama 24 jam. Selain itu, layanan website sangat luas jangkauannya dan banyak pemakainya.

Data adalah objek penelitian, realitas yang kita jadikan fokus penelitian, termasuk tempat, partisipan, dan kejadian yang melingkupi fokus tersebut (Santosa, 2017:52). Dalam penelitian kualitatif, data biasanya berupa deskripsi fokus beserta tempat (situs), kejadian, perilaku, dan interaksi objek penelitian dengan segala konteks yang mengiringinya. Data dalam penelitian ini adalah penggunaan modalitas yang terdapat pada teks iklan kuliner khas Semarang.

Metode penyediaan data menggunakan metode simak atau penyimakan karena memang berupa penyimakan: dilakukan dengan menyimak, yaitu menyimak penggunaan bahasa (Sudaryanto, 2015:203). Ini dapat disejajarkan dengan metode pengamatan atau observasi. Teknik dasar yang dipergunakan adalah teknik sadap; sedangkan teknik lanjutan yang dipergunakan adalah teknik simak bebas libat cakap (SBLC) dan teknik catat (Sudaryanto, 2015:204206).

Metode analisis data yang dipergunakan adalah metode agih, alat penentunya justru bagian dari bahasa yang bersangkutan itu sendiri (Sudaryanto, 2015:18). Teknik yang digunakan adalah teknik dasar dan teknik 
Nanik Setyawati, Riyadi Santosa, Sumarlam, Dwi Purnanto - Modalitas sebagai Peranti Sistem Appraisal dalam Teks Iklan Kuliner Khas Semarang di Media Internet

lanjutan. Teknik dasarnya adalah teknik bagi unsur langsung atau teknik BUL (Sudaryanto, 2015:37). Disebut demikian karena cara yang digunakan pada awal kerja analisis ialah membagi satuan lingual datanya menjadi beberapa bagian atau unsur; dan unsur-unsur yang bersangkutan dipandang sebagai bagian yang langsung membentuk satuan lingual yang dimaksud. Adapun alat penggerak bagi alat penentu-atau pirantinya-ialah daya bagi yang bersifat intuitif, atau secara singkat: intuisi-tentu saja intuisi kebahasaan atau intuisi lingual; sedangkan alat (penentu)-nya adalah jeda, baik jeda yang silabik atau sendi maupun yang sintaktik atau ruas.

Bertolak dari penggunaan teknik dasar BUL yang menghasilkan unsurunsur itulah baru dapat digunakan teknik-teknik lanjutannya. Teknik lanjutan yang diterapkan dalam penelitian ini adalah teknik lesap dan teknik ganti. Kegunaan teknik lesap dalam analisis ini untuk mengetahui kadar keintian unsur yang dilesapkan, yaitu unsur yang menjadi penanda modalitas. Jika unsur penanda modalitas itu dilesapkan, hasilnya akan berupa satuan lingual yang tidak ditemukan adanya eksplorasi sikap yang dinegosiasikan di dalam teks tersebut. Teknik ganti digunakan untuk mengetahui kadar kesamaan kelas atau kategori unsur terganti atau unsur ginanti dengan unsur pengganti, khususnya bila tataran pengganti sama dengan tataran terganti atau tataran ginanti. Dalam hal ini, diterapkan pada saat mengetahui bagian penanda modalitas. Metode dan teknik penyajian hasil analisis data menggunakan menggunakan metode penyajian kaidah yang bersifat informal.

\section{HASIL DAN PEMBAHASAN}

Pada tabel 1 berikut ini penulis sajikan teks iklan kuliner khas Semarang di media internet yang di dalamnya terdapat penggunaan modalitas.

\section{Tabel 1. Modalitas dalam Teks Iklan Kuliner Khas Semarang di Media Internet

\begin{tabular}{cc}
\hline No. & Data \\
\hline 1 & Delivery Lunpia Delight bisa lewat aplikasi gojek. \\
\hline
\end{tabular}


Nanik Setyawati, Riyadi Santosa, Sumarlam, Dwi Purnanto - Modalitas sebagai Peranti Sistem Appraisal dalam Teks Iklan Kuliner Khas Semarang di Media Internet

\begin{tabular}{|c|c|}
\hline No. & Data \\
\hline 2 & $\begin{array}{l}\text { Lumpia Cik Meme kuliner khas Semarang yang } \\
\text { wajib dicoba. }\end{array}$ \\
\hline 3 & $\begin{array}{l}\text { Oleh-oleh khas Semarang harga hemat rasa } \\
\text { mantab musti dicoba! }\end{array}$ \\
\hline 4 & $\begin{array}{l}\text { Lunpia Express nampol. Enaknya emang pol. Ayo } \\
\text { dicoba. }\end{array}$ \\
\hline 5 & $\begin{array}{l}\text { Musti coba Lunpia Express Jl. Gajah Mada 142AA } \\
\text { Semarang. }\end{array}$ \\
\hline 6 & $\begin{array}{l}\text { Jajan di Lunpia Express bisa menyebabkan hati } \\
\text { senang karena keenakan. }\end{array}$ \\
\hline 7 & $\begin{array}{l}\text { Lunpia Express. Pelayanan cepat dan ramah. } \\
\text { Lokasi mudah dijangkau. Harga tetap murah. } \\
\text { Tempat bersih dan nyaman. "Kudu mampir coba } \\
\text { nih" }\end{array}$ \\
\hline 8 & $\begin{array}{l}\text { Lunpia Express sajikan yang terbaik. Kudu } \\
\text { mampir nih! }\end{array}$ \\
\hline 9 & Yuk jajan Lunpia Express. Free delivery. \\
\hline 10 & $\begin{array}{l}\text { Kami antar gratis. Kalo mau mampir ke sini aja: Jl. } \\
\text { Gajah Mada } 142 \text { AA Semarang. }\end{array}$ \\
\hline 11 & $\begin{array}{l}\text { Rekomendasi makanan khas Semarang yang mesti } \\
\text { dicoba. }\end{array}$ \\
\hline 12 & $\begin{array}{l}\text { Lunpia } 57 \text { merupakan produk olahan yang } \\
\text { terbuat dari bahan-bahan pilihan sehingga } \\
\text { menghasilkan cita rasa dan aroma yang terbaik. } \\
\text { Tanpa bau rebung yang menyengat. Ayo Wisata } \\
\text { ke Semarang dan Jawa Tengah. }\end{array}$ \\
\hline 13 & $\begin{array}{l}\text { Loenpia Semarang Special DJOE. Kalian musti } \\
\text { cobain loenpia ini gaizz!! }\end{array}$ \\
\hline 14 & $\begin{array}{l}\text { Kalo mau ngerasain kelezatan lumpia Kuwiki, } \\
\text { tolong abaikan diet dan jarum timbangan. }\end{array}$ \\
\hline 15 & $\begin{array}{l}\text { Dapat mengirim ke 'Luar Kota' dan ke 'Luar } \\
\text { Pulau Jawa' yang terjangkau. }\end{array}$ \\
\hline 16 & $\begin{array}{l}\text { Wingko Babat N.N. Meniko asli cap Stoom Mini } \\
\text { dibuat oleh: N.N. Meniko Kp. Pandean } \\
\text { Tamanharjo } 83 \text { Semarang dapat dibeli di mana- } \\
\text { mana. }\end{array}$ \\
\hline 17 & $\begin{array}{l}\text { Moaci Gemini Semarang sudah bisa dibeli lewat } \\
\text { Tokopedia. }\end{array}$ \\
\hline 18 & $\begin{array}{l}\text { Tahu bakso Semarang New Citra sangat enak, } \\
\text { nagih, dan pengin lagi. Yuk order. } \\
\text { Mie Titee A Kuang. Mie Titee masih } 3 \text { pax. }\end{array}$ \\
\hline 19 & $\begin{array}{l}\text { Monggo dihabiskan. } \\
\text { Tahu gimbal Semarang porsi brutal. Mau pingsan }\end{array}$ \\
\hline 20 & $\begin{array}{l}\text { kekenyangan. } \\
\text { Kuliner Semarang nasi ayam wajib coba! }\end{array}$ \\
\hline 21 & Bumbu super ajaib. Bikin nagih. Wajib coba! Babat \\
\hline 22 & $\begin{array}{l}\text { Gongso Pak Taman. } \\
\text { Monggo merapat tahun baru di alun-alun mampir }\end{array}$ \\
\hline
\end{tabular}


Nanik Setyawati, Riyadi Santosa, Sumarlam, Dwi Purnanto - Modalitas sebagai Peranti Sistem Appraisal dalam Teks Iklan Kuliner Khas Semarang di Media Internet

\begin{tabular}{cl}
\hline No. & \multicolumn{1}{c}{ Data } \\
\hline 23 & ke Pak Kumis. \\
& $\begin{array}{l}\text { Yang berada di luar kota Semarang tidak perlu } \\
\text { khawatir, Lumpia Semarang Online bisa } \\
\text { mengirim sampai ke luar pulau, dan hampir } \\
\text { menjangkau seluruh wilayah Indonesia. }\end{array}$ \\
\hline
\end{tabular}

Berdasarkan hasil identifikasi data yang telah ditampilkan di atas, dalam tulisan ini akan dideskripsikan jenis-jenis modalitas dalam teks iklan kuliner khas Semarang di media internet.

\section{Modalitas Intensional}

Modalitas intensional yang ditemukan dalam teks iklan kuliner menyatakan makna 'keinginan', 'ajakan', dan 'permintaan'.

\section{Modalitas Intensional Bermakna 'Keinginan'}

Modalitas intensional dalam teks iklan kuliner menyatakan makna 'keinginan', 'ajakan', dan 'permintaan'. Hal tersebut dapat diperhatikan pada teks berikut ini.

(1)Kami antar gratis. Kalo mau mampir ke sini aja: Jl. Gajah Mada 142 AA Semarang.

(2)Kalo mau ngerasain kelezatan lumpia Kuwiki, tolong abaikan diet dan jarum timbangan.

(3)Tahu gimbal Semarang porsi brutal. Mau pingsan kekenyangan.

Makna modalitas pada ketiga teks di atas dapat terlihat dengan hadirnya unsur leksikal mau. Makna modalitas tidak dapat diketahui, jika pada ketiga teks tersebut melesapkan penggunaan kata mau. Kata mau pada teks (1) dan (2) berfungsi sebagai modalitas yang bermakna 'keinginan' dengan kadar 'kemauan'. Pada teks (1) menggambarkan sikap pengiklan yang bersedia mengantar calon konsumen ke Jl. Gajah Mada 142 AA Semarang yang ada kemauan atau hendak mampir berkuliner. Pada teks (2) pengiklan mencoba mengenalkan kuliner lumpia Kuwiki kepada calon konsumen yang berkemauan atau hendak merasakan kelezatannya. Kata mau pada teks (3) 
Nanik Setyawati, Riyadi Santosa, Sumarlam, Dwi Purnanto - Modalitas sebagai Peranti Sistem Appraisal dalam Teks Iklan Kuliner Khas Semarang di Media Internet

berkadar 'keakanan'. Teks tersebut menggambarkan sikap konsumen yang merasa akan pingsan karena kekenyangan setelah menikmati kuliner tahu gimbal Semarang dengan porsi yang lebih.

Kata mau pada teks (1) - (3) dapat digantikan dengan kata hendak dan akan. Perhatikan teks (1a) - (3a) berikut ini.

(1a) Kami antar gratis.

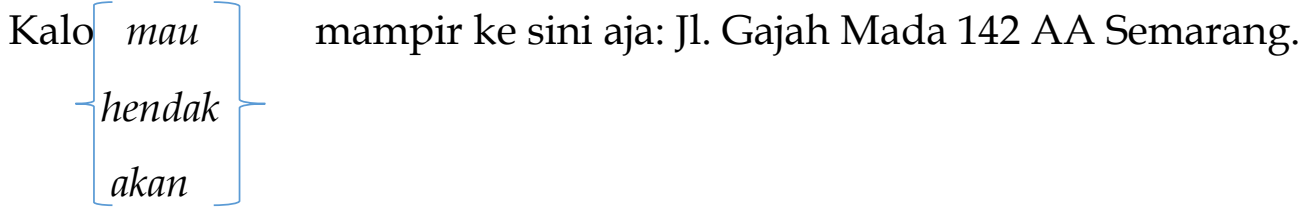

(2a) Kalo mau ngerasain kelezatan lumpia Kuwiki, tolong abaikan diet dan $\left\{\begin{array}{c}\text { hendak } \\ \text { akan }\end{array}\right.$

jarum timbangan.

(3a) Tahu gimbal Semarang porsi brutal. $[$ Mau $]$ pingsan kekenyangan.

$$
\left\{\begin{array}{c}
\text { Hendak } \\
\text { Akan }
\end{array}\right\}
$$

\section{Modalitas Intensional Bermakna 'Ajakan'}

Selain menyatakan 'keinginan', modalitas intensional juga menyatakan makna 'ajakan'. Hal tersebut dapat dicermati pada keenam teks berikut.

(4)Lunpia Express nampol. Enaknya emang pol. Ayo dicoba.

(5)Lunpia 57 merupakan produk olahan yang terbuat dari bahan-bahan pilihan sehingga menghasilkan cita rasa dan aroma yang terbaik. Tanpa bau rebung yang menyengat. Ayo wisata ke Semarang dan Jawa Tengah.

(6) Yuk jajan Lunpia Express. Free delivery.

(7) Tahu bakso Semarang New Citra sangat enak, nagih, dan pengin lagi. Yuk order.

(8)Mie Titee A Kuang. Mie Titee masih 3 pax. Monggo dihabiskan.

(9)Monggo merapat tahun baru di alun-alun mampir ke Pak Kumis. 
Makna modalitas 'keinginan' dengan kadar 'ajakan' pada keenam teks di atas bisa diidentifikasi dari pemakaian penanda modalitas ayo, yuk, dan monggo 'mari' atau ayo'. Berbeda jika penanda modalitas tersebut dilesapkan dari keenam teks di atas, sikap pengiklan tidak bisa diidentifikasi. Dengan memanfaatkan penanda modalitas ayo, pada teks (4) pengiklan mengajak calon konsumen untuk mencoba Lunpia Express yang nampol 'rasa yang enak dan pas', yang enaknya pol 'maksimal'. Ajakan pengiklan dengan menggunakan kata ayo juga dapat ditemukan pada teks (5). Pada teks tersebut pengiklan mengajak calon konsumen untuk wisata ke Semarang agar bisa menikmati Lunpia 57 yang bercita rasa dan beraroma baik.

Ajakan pengiklan kepada calon konsumen pada teks (6) dan teks (7) dengan memanfaatkan penanda modalitas yuk. Teks (6) mencerminkan ajakan pengiklan kepada calon konsumen untuk jajan 'membeli' Lunpia Express; sedangkan teks (7) merupakan ajakan pengiklan kepada calon konsumen agar order 'memesan' kuliner tahu bakso Semarang New Citra yang enak yang membuat ketagihan.

Kata monggo dalam bahasa Jawa yang sejajar dengan 'mari' atau 'ayo' yang terdapat pada teks (8) dan (9) sebagai alat modalitas dipilih oleh pengiklan untuk mengajak calon konsumen. Pada teks (8) calon konsumen diajak menghabiskan mie titee A Kuang yang masih 3 pax 'pak'; sedangkan pada teks (9) calon konsumen diajak merapat pada saat tahun baru ke alunalun mampir di warung Pak Kumis (yang khas nasi goreng babat gongso).

Pemakaian penanda modalitas ayo pada teks (4) dan (5) dapat digantikan dengan kata mari (lah); kata yuk pada teks (6) dan (7) dapat digantikan dengan unsur leksikal mari (lah) dan ayo (lah); sedangkan penanda monggo 'mari' atau ayo' dapat digantikan dengan kata mari (lah) dan ayo (lah). Silakan dicermati teks (4a) - (9a) berikut.

(4a) Lunpia Express nampol. Enaknya emang pol. $\left\{\begin{array}{l}\text { Ayo } \\ \text { Mari (lah) }\end{array}\right\}^{\text {dicoba. }}$ 
Nanik Setyawati, Riyadi Santosa, Sumarlam, Dwi Purnanto - Modalitas sebagai Peranti Sistem Appraisal dalam Teks Iklan Kuliner Khas Semarang di Media Internet

(5a) Lunpia 57 merupakan produk olahan yang terbuat dari bahan-bahan pilihan sehingga menghasilkan cita rasa dan aroma yang terbaik. Tanpa bau rebung yang menyengat.

$\left\{\begin{array}{l}\text { Ayo } \\ \text { Mari (lah) }\end{array}\right\} \quad$ wisata ke Semarang dan Jawa Tengah.

(6a) $\left\{\begin{array}{l}Y u k \\ \text { Ayo (lah) } \\ \text { Mari (lah) }\end{array}\right\}$ jajan Lunpia Express. Free delivery.

(7a) Tahu bakso Semarang New Citra sangat enak, nagih, dan pengin lagi.

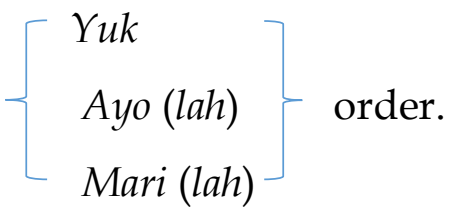

(8a) Mie Titee A Kuang. Mie Titee masih 3 pax. —Monggo dihabiskan.

$$
\begin{aligned}
& \text { Ayo (lah) } \\
& \text { Mari (lah) }
\end{aligned}
$$

(9a) Monggo 7 merapat tahun baru di alun-alun mampir ke Pak Kumis. $\left\{\begin{array}{l}\text { Ayo }(\text { lah }) \\ \text { Mari (lah) }\end{array}\right.$

\section{Modalitas Intensional Bermakna 'Permintaan'}

Modalitas intensional dengan makna 'permintaan' ditandai dengan pemakaian kata tolong. Hal tersebut dapat dicermati pada teks berikut.

(10) Kalo mau ngerasain kelezatan lumpia Kuwiki, tolong abaikan diet dan jarum timbangan.

Jika kata tolong dilesapkan pada teks (10), makna 'permintaan' tidak bisa diketahui. Teks (10) memperlihatkan pemakaian kata tolong sebagai permintaan pengiklan kepada konsumen untuk mengabaikan diet dan jarum timbangan agar bisa merasakan kelezatan lumpia Kuwiki. Kata tolong dapat digantikan dengan unsur leksikal saya minta, saya mohon, silakan, coba, dan mohon. Perhatikan teks (10a) berikut. 
Nanik Setyawati, Riyadi Santosa, Sumarlam, Dwi Purnanto - Modalitas sebagai Peranti Sistem Appraisal dalam Teks Iklan Kuliner Khas Semarang di Media Internet

(10a) Kalo mau ngerasain kelezatan lumpia Kuwiki, [ tolong abaikan diet dan $\left\{\begin{array}{l}\text { saya minta } \\ \text { saya mohon } \\ \text { silakan } \\ \text { coba } \\ \text { mohon }\end{array}\right\}$

jarum timbangan.

\section{Modalitas Epistemik}

Dalam teks iklan kuliner ditemukan modalitas epistemik yang bermakna 'kemungkinan' dan 'keharusan'.

\section{Modalitas Epistemik Bermakna 'Kemungkinan'}

Kata bisa dan dapat merupakan penanda modalitas epistemik yang bermakna 'kemungkinan'. Perhatikan ketiga teks berikut.

(11) Delivery Lunpia Delight bisa lewat aplikasi gojek.

(12) Moaci Gemini Semarang sudah bisa dibeli lewat Tokopedia.

(13) Wingko Babat N.N. Meniko asli cap Stoom Mini dibuat oleh: N.N. Meniko Kp. Pandean Tamanharjo 83 Semarang dapat dibeli di mana-mana.

Makna 'kemungkinan' pada teks (11) dan (12) terasa ketika ditambahkan modalitas bisa, sedangkan makna 'kemungkinan' pada teks (13) terlihat dengan hadirnya kata dapat. Jika penanda modalitas pada ketiga teks dilesapkan akan tidak terlihat makna modalitas tersebut. Penanda leksikal bisa yang terdapat pada teks (11) menyiratkan bahwa pengiklan mencoba menyampaikan kepada calon konsumen kemungkinan yang bisa dilakukan calon konsumen yang akan menikmati Lunpia Delight dengan cara membeli lewat aplikasi gojek. Pada teks (12) pengiklan mencoba mengenalkan kepada calon konsumen tentang kuliner Moaci Gemini Semarang yang sudah memungkinkan dibeli lewat Tokopedia. Kata dapat pada teks (13) merupakan penanda modalitas epistemik dengan makna 'kemungkinan' juga. Pada teks tersebut pengiklan menyampaikan pesan bahwa kuliner wingko babat N.N. Meniko Cap Stoom Mini sudah dimungkinkan dapat dibeli di berbagai tempat. 
Nanik Setyawati, Riyadi Santosa, Sumarlam, Dwi Purnanto - Modalitas sebagai Peranti Sistem Appraisal dalam Teks Iklan Kuliner Khas Semarang di Media Internet

Penanda modalitas yang dipakai pada teks (11) dan (12) dapat digantikan dengan unsur leksikal lain, seperti yang terlihat pada teks (11a) dan (12a) berikut.

(11a) Delivery Lunpia Delight

$$
\left\{\begin{array}{l}
\text { bisa } \\
\text { dapat } \\
\text { boleh } \\
\text { mungkin } \\
\text { dapat saja } \\
\text { bisa saja } \\
\text { boleh saja }
\end{array}\right\}
$$

$\left\{\begin{array}{l}\text { bisa } \\ \text { dapat } \\ \text { boleh } \\ \text { mungkin } \\ \text { dapat saja } \\ \text { bisa saja } \\ \text { boleh saja }\end{array}\right\}$

lewat aplikasi gojek.

dibeli lewat Tokopedia.

Penanda modalitas dapat pada teks (13) dapat digantikan dengan unsur leksikal bisa, boleh, mungkin, dapat saja, bisa saja, boleh saja, dan boleh jadi. Perhatikan teks (13a) berikut.

(13a) Wingko Babat N.N. Meniko asli cap Stoom Mini dibuat oleh: N.N. Meniko Kp. Pandean Tamanharjo 83 Semarang $\left[\begin{array}{l}\text { dapat dibeli di mana-mana. } \\ \text { bisa } \\ \text { boleh } \\ \text { mungkin } \\ \text { dapat saja } \\ \text { bisa saja } \\ \text { boleh saja } \\ \text { boleh jadi }\end{array} \mid\right.$ 
HALUAN SASTRA BUDAYA Vol 5 (1), 2021 • ISSN Print: 0852-0933・ ISSN Online: 2549-1733

Nanik Setyawati, Riyadi Santosa, Sumarlam, Dwi Purnanto - Modalitas sebagai Peranti Sistem Appraisal dalam Teks Iklan Kuliner Khas Semarang di Media Internet

\section{Modalitas Epistemik Bermakna 'Keharusan'}

Jenis modalitas epistemik yang bermakna 'keharusan' ditandai dengan pemanfaatan kata wajib, musti, kudu 'harus', dan mesti. Simak keempat teks berikut.

(14) Lumpia Cik Meme kuliner khas Semarang yang wajib dicoba.

(15) Musti coba Lunpia Express Jl. Gajah Mada 142AA Semarang.

(16) Lunpia Express. Pelayanan cepat dan ramah. Lokasi mudah dijangkau. Harga tetap murah. Tempat bersih dan nyaman. "Kudu mampir coba nih".

(17) Rekomendasi makanan khas Semarang yang mesti dicoba.

Jika penanda modalitas pada keempat teks tersebut dilesapkan akan tidak terlihat makna modalitas tersebut. Penanda wajib pada teks (14) yang dimanfaatkan oleh pengiklan untuk menggiring calon konsumen harus mencoba kuliner khas Semarang Lumpia Cik Meme. Teks (15) dengan penanda musti menyiratkan bahwa pengiklan mempengaruhi calon konsumen harus mencoba Lunpia Express di Jl. Gajah Mada 142AA Semarang. Melihat pelayanan cepat dan ramah, lokasi mudah dijangkau, harga tetap murah, tempat bersih dan nyaman; pengiklan berani mengharuskan para calon konsumen mampir untuk mencoba kuliner Lunpia Express terlihat pada teks (16). Hal tersebut dapat dilihat pada penanda $k u d u$ dalam bahasa Jawa yang sejajar dengan 'harus' yang menjadi pilihan penanda modalitasnya. Pengiklan mempengaruhi calon konsumen harus mencoba makanan khas Semarang juga ditemui pada teks (17) dengan memanfaatkan kata mesti.

Kata wajib pada teks (14) dapat digantikan dengan kata harus, mesti, perlu,dan patut; kata musti pada teks (15) dapat digantikan dengan kata wajib, harus, mesti, perlu, dan patut; kata kudu 'harus' pada teks (16) dapat digantikan dengan kata wajib, harus, mesti, perlu, dan patut; sedangkan kata mesti pada teks (17) dapat digantikan dengan kata wajib, harus, perlu, dan patut. Simak teks (14a) - (17a) berikut. 
Nanik Setyawati, Riyadi Santosa, Sumarlam, Dwi Purnanto - Modalitas sebagai Peranti Sistem Appraisal dalam Teks Iklan Kuliner Khas Semarang di Media Internet

(14a) Lumpia Cik Meme kuliner khas Semarang yang $\left.\begin{array}{l}\text { wajib } \\ \text { harus } \\ \text { mesti } \\ \text { perlu } \\ \text { patut }\end{array}\right\}$

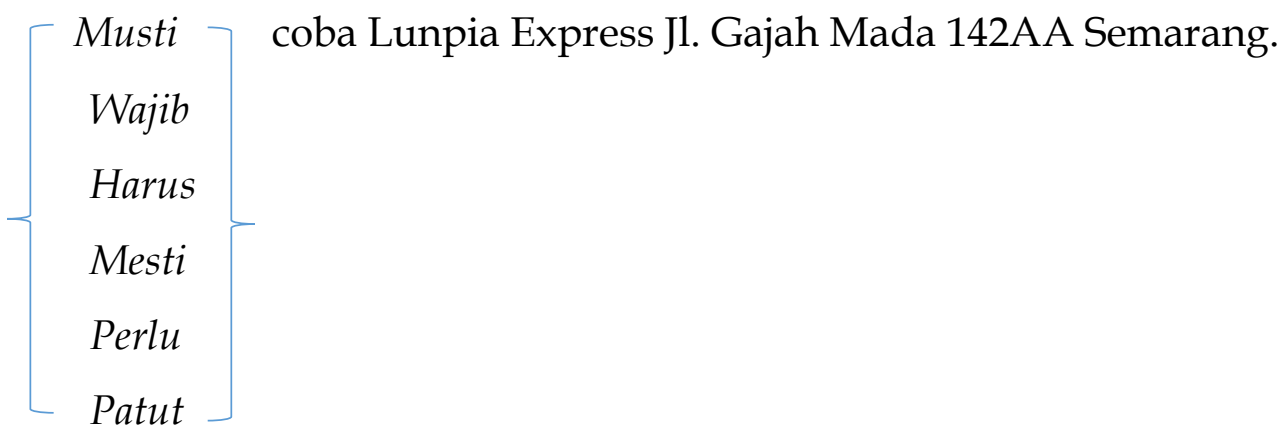

(16a) Lunpia Express. Pelayanan cepat dan ramah. Lokasi mudah dijangkau. Harga tetap murah. Tempat bersih dan nyaman. Kudu mampir coba nih.

Wajib

Harus

Mesti

Perlu

Patut

$(17 \mathrm{a})$

Rekomendasi makanan khas Semarang yang $\left\{\begin{array}{c}\text { mesti } \\ \text { wajib } \\ \text { harus } \\ \text { perlu } \\ \text { patut }\end{array}\right\}$

\section{Modalitas Deontik}

Jenis modalitas deontik ini hanya ditemukan satu makna yaitu 'perintah'. Beberapa teks yang mengandung makna tersebut dapat dilihat pada teks (18) - (22) berikut.

(18) Oleh-oleh khas Semarang harga hemat rasa mantab musti dicoba!

(19) Loenpia Semarang Special DJOE. Kalian musti cobain loenpia ini gaizz!! 
Nanik Setyawati, Riyadi Santosa, Sumarlam, Dwi Purnanto - Modalitas sebagai Peranti Sistem Appraisal dalam Teks Iklan Kuliner Khas Semarang di Media Internet

(20) Kuliner Semarang nasi ayam wajib coba!

(21) Bumbu super ajaib. Bikin nagih. Wajib coba! Babat Gongso Pak Taman.

(22) Lunpia Express sajikan yang terbaik. Kudu mampir nih!

Makna 'perintah' bisa dirasakan dengan hadirnya penanda modalitas pada masing-masing teks. Penggunaan kata musti pada teks mengisyaratkan sebuah perintah dari pengiklan yang ditujukan kepada calon konsumen untuk mencoba oleh-oleh khas Semarang dengan harga hemat rasa mantab. Makna perintah yang ditemukan pada teks (19) dengan pemanfaatan kata musti juga. Pada teks tersebut calon konsumen diperintah oleh pengiklan untuk mencoba Loenpia Semarang Special DJOE. Dua teks berikutnya yaitu teks (20) dan (21) pengiklan menggunakan unsur leksikal wajib untuk memerintah calon konsumen. Pada teks (20) kuliner Semarang nasi ayam yang diperintahkan untuk dicoba; sedangkan pada teks (21) calon konsumen diperintahkan untuk mencoba babat gongso Pak Taman dengan bumbu super ajaib yang bikin konsumen ketagihan. Kata $k u d u$ yang ditambahkan pada teks (22) mengandung sebuah perintah dari pengiklan untuk mampir menikmati Lunpia Express dengan sajian yang terbaik.

Penanda musti pada teks (18) dan (19) dapat digantikan dengan unsur leksikal wajib, mesti, dan harus; penanda wajib pada teks (20) dan (21) dapat digantikan dengan kata mesti dan harus; sedangkan penanda kudu 'harus' pada teks (22) dapat digantikan dengan kata wajib, mesti, dan harus. Perhatikan teks (18a) - (21a) berikut.

(18a) Oleh-oleh khas Semarang harga hemat rasa mantab

$$
\left.\begin{array}{l}
\text { musti } \\
\text { wajib } \\
\text { mesti } \\
\text { harus }
\end{array}\right\}
$$

(19a) Loenpia Semarang Special DJOE. Kalian musti `cobain loenpia ini gaizz!!

$$
\left\{\begin{array}{c}
\text { wajib } \\
\text { mesti } \\
\text { harus }
\end{array}\right\}
$$


Nanik Setyawati, Riyadi Santosa, Sumarlam, Dwi Purnanto - Modalitas sebagai Peranti Sistem Appraisal dalam Teks Iklan Kuliner Khas Semarang di Media Internet

(20a) Kuliner Semarang nasi ayam

$\left\{\begin{array}{l}\text { wajib } \\ \text { mesti } \\ \text { harus }\end{array}\right\}^{\text {coba! }}$

(21a) Bumbu super ajaib. Bikin nagih. Wajib coba! Babat Gongso Pak Taman

$$
\left\{\begin{array}{l}
\text { Mesti } \\
\text { Harus }
\end{array}\right\}
$$

(22a) Lunpia Express sajikan yang terbaik.

$\left\{\begin{array}{c}\text { Kudu } \\ \text { Wajib } \\ \text { Mesti } \\ \text { Harus }\end{array}\right\}$

\section{Modalitas Dinamik}

Jenis modalitas dinamik yang ditemukan bermakna 'kemampuan'. Perhatikan teks berikut.

(23) Jajan di Lunpia Express bisa menyebabkan hati senang karena keenakan.

(24) Yang berada di luar kota Semarang tidak perlu khawatir, Lumpia Semarang Online bisa mengirim sampai ke luar pulau, dan hampir menjangkau seluruh wilayah Indonesia.

(25) Dapat mengirim ke 'Luar Kota' dan ke 'Luar Pulau Jawa' yang terjangkau.

Penanda modalitas pada ketiga menggambarkan makna 'kemampuan'. Kata bisa yang dimanfaatkan pada teks (23) mengandung makna bahwa jajan 'membeli' Lunpia Express mampu membuat hati senang karena enaknya. Teks (24) memanfaatkan penanda modalitas bisa untuk menyatakan kemampuan dari produsen Lunpia Semarang Online untuk mengirim sampai ke luar pulau, dan hampir menjangkau seluruh wilayah Indonesia. Kata dapat pada teks (25) juga menyatakan kemampuan mengirim ke 'Luar Kota' dan ke 'Luar Pulau Jawa' yang terjangkau. Jika penanda modalitas pada masing-masing teks di atas dilesapkan, makna 'kemampuan' pada teks tersebut tidak bisa dirasakan.

Kata bisa pada teks (23) dan teks (24) dapat digantikan dengan kata dapat, mampu, dan sanggup; sedangkan kata dapat pada teks (25) dapat digantikan dengan bisa, mampu, dan sanggup. Perhatikan teks (23a) - (25a) berikut. 
HALUAN SASTRA BUDAYA Vol 5 (1), 2021 • ISSN Print: 0852-0933・ ISSN Online: 2549-1733

Nanik Setyawati, Riyadi Santosa, Sumarlam, Dwi Purnanto - Modalitas sebagai Peranti Sistem Appraisal dalam Teks Iklan Kuliner Khas Semarang di Media Internet

(23a) Jajan di Lunpia Express bisa menyebabkan hati senang karena keenakan.

$$
\begin{gathered}
\text { dapat } \\
\text { mampu } \\
\text { sanggup }
\end{gathered}
$$

(24a) Yang berada di luar kota Semarang tidak perlu khawatir, Lumpia Semarang Online bisa mengirim sampai ke luar pulau, dan hampir

$$
\left\{\begin{array}{l}
\text { dapat } \\
\text { mampu } \\
\text { sanggup }
\end{array}\right.
$$

menjangkau seluruh wilayah Indonesia.

(25a)

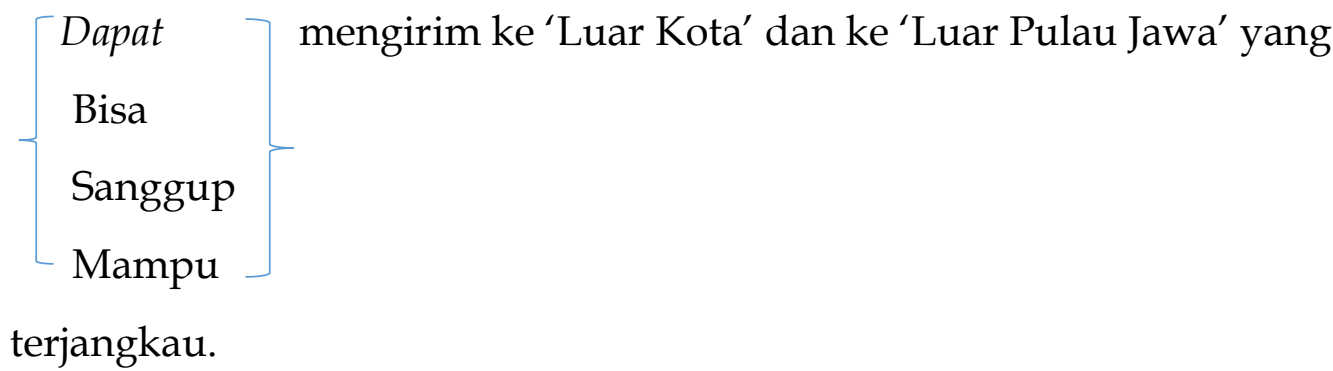

Demikian yang bisa penulis deskripsikan pada pembahasan tentang modalitas sebagai peranti sistem appraisal dalam teks iklan kuliner khas Semarang di media internet.

\section{SIMPULAN}

Berdasarkan pembahasan di atas dapat disimpulkan bahwa dalam teks iklan kuliner khas Semarang di media internet ditemukan pemakaian salah satu piranti appraisal subkategori modalitas dengan empat jenis, yaitu modalitas intensional, epistemik, deontik, dan dinamik.

Jenis modalitas intensional dengan makna 'keinginan' dengan kadar 'kemauan' dan 'keakanan' keduanya dengan penanda mau; makna 'ajakan' ditandai dengan kata yuk, ayo, dan monggo 'mari' atau 'ayo'; dan makna 
Nanik Setyawati, Riyadi Santosa, Sumarlam, Dwi Purnanto - Modalitas sebagai Peranti Sistem Appraisal dalam Teks Iklan Kuliner Khas Semarang di Media Internet

'permintaan' ditandai dengan kata tolong. Jenis modalitas epistemik dengan makna 'kemungkinan' berpenanda bisa dan dapat dan makna 'keharusan' dengan penanda wajib, musti, kudu 'harus, dan mesti. Jenis modalitas deontik dengan makna 'perintah' menggunakan penanda musti, wajib, dan kudu 'harus'. Jenis modalitas dinamik dengan makna 'kemampuan' memanfaatkan unsur leksikal bisa dan dapat. Penulis berharap tulisan ini dapat membantu mengupayakan pembuatan iklan yang lebih baik dan inovatif dengan mempertimbangkan pemanfaatan unsur kebahasaan yang lebih tepat.

\section{DAFTAR PUSTAKA}

Aisyah, Siti Nur. (2019). Modalitas Bahasa Indonesia dalam talk show Mata Najwa. Jurnal Ilmiah Program Studi Pendidikan Bahasa E Sastra Indonesia Belajar Bahasa, 4(2), 161 - 240.

Alwi, Hasan. (1992). Modalitas dalam Bahasa Indonesia. Yogyakarta: Kanisius (Anggota IKAPI).

Amrullah, Firda; dkk. (2020). Modalitas dalam teks berita hoaks: kajian linguistik sistemik fungsional. Jurnal Ilmu Budaya, 8(1), 37 - 45.

Arifin, Zaenal. (2000). Pemakaian bahasa dalam iklan berita dan papan reklame. Jakarta: Pusat Pembinaan dan Pengembangan Bahasa Departemen Pendidikan dan Kebudayaan.

Cahyadi, Teguh Dwi. (2015). Kata kerja bantu modal sebagai pengungkap modalitas bahasa Inggris dan padanannya dalam Bahasa Indonesia. (Tesis tidak diterbitkan). Yogyakarta: S-2 Ilmu Linguistik, Universitas Gadjah Mada.

Chaer, Abdul. (1994). Linguistik umum. Jakarta: Rineka Cipta.

Charmilasari. (2018). Modalitas pada wacana kelas: kajian linguistik sistemik fungsional. Jurnal Onoma, 4(2), 138 - 156.

Creswell, John W. (2015). Penelitian kualitatif E desain riset: memilih di antara lima pendekatan. Alih Bahasa oleh Ahmad Lintang Lazuardi. Dari Qualitative Inquiry \& Research Design: Choosing Among Five Approaches (2013). Cetakan 1. Yogyakarta: Pustaka Pelajar.

Faradi, Abdul Azis. (2015). Kajian modalitas linguistik fungsional sistemik pada teks debat Capres-Cawapres pada Pilpres 2014 - 2019 dan Relevansinya dengan Pembelajaran Wacana di Sekolah. RETORIKA, 1(2), 233 - 249.

Gardjito, Murdijati; Rhaesfaty Galih Putri; \& Swastika Dewi. (2016). Profil struktur, bumbu, dan bahan dalam kuliner Indonesia. Yogyakarta: Gadjah Mada University Press. 
Jefkins, Frank. (1994). Periklanan. Edisi Ketiga. Jakarta: Erlangga.

Karsana, Deni. (2015). Mengurai dilema modalitas dalam bahasa Kaili (parse dilemma modality in Kaili Language), Majalah Ilmiah Bahasa dan Sastra SALINGKA, 12(2), 175 - 182.

Khaofia, Suci. (2018). Modalitas sebagai realisasi makna interpersonal dalam Mata najwa on Stage "Semua karena Ahok", Prasasti: Journal of Linguistics, 3(2), 222 - 234.

Kompasiana.com. (2015, 24 Juni). “Sejarah kuliner Semarang”. Diakses 22 Maret 2018, dari https://www.kompasiana.com/ardhi.dikka/ 5530004b6ea83406038b4634/sejarah-kuliner-semarang.

Kridalaksana, Harimurti. (1993). Kamus linguistik. Jakarta: PT. Gramedia Pustaka Utama.

Martin, J.R. \& David Rose. (2007). Working with discourse: meaning beyond the clause. London \& New York: Continuum.

Moleong, Lexy J. (2010). Metodologi penelitian kualitatif: edisi revisi. Bandung: Remaja Rosda Karya.

Musdolifah, Ari. (2018). Keterangan modalitas dalam berita "Alexis yang Terus Exis" pada Majalah Tempo Edisi 29 Januari - 4 Februari 2018, Jurnal BASA TAKA, 1(1), 1 - 10.

Oktavianti, Ikmi Nur; Prayogi, Icuk. (2018). Realisasi temporalitas, aspektualitas, dan modalitas dalam bahasa Inggris dan Bahasa Indonesia. Adabiyyāt, 2(2), 181 - 201.

Prihantoro, Edy; Fitriani, Dinda Rakhma. (2015). Modalitas dalam teks berita media online. Prosiding PESAT (Psikologi, Ekonomi, Sastra, Arsitektur $\mathcal{E}$ Teknik Sipil), 6, 17 - 25.

Santosa, Riyadi. (2017). Metode penelitian kualitatif kebahasaan. Surakarta: UNS Press.

Sudaryanto. (2015). Metode dan aneka teknik analisis bahasa: pengantar penelitian wahana kebudayaan secara linguistis. Yogyakarta: Universitas Sanata Dharma APPTI Asosiasi Penerbit Perguruan Tinggi Indonesia.

Surakhmad, Winarno. (1990). Pengantar penelitian ilmiah: dasar, metode, dan teknik. Bandung: Tarsito.

Wiratno, Tri. (2018). Pengantar ringkas linguistik sistemik funsional. Cetakan I. Yogyakarta: Pustaka Pelajar (Anggota IKAPI). 